\title{
Physiotherapy protocol during initial postoperative period of arthroscopy in horses ${ }^{1}$
}

\author{
Fernanda C. Stievani2*, Thais S.L. Machado ${ }^{3}$, Kaio B. Bezerra ${ }^{3}$, Marilene M. Silva ${ }^{4}$, \\ Raquel Y.A. Baccarin ${ }^{3}$ and Luis C.L.C. Silva ${ }^{3}$
}

\begin{abstract}
Stievani F.C., Machado T.S.L., Bezerra K.B., Silva M.M., Baccarin R.Y.A. \& Silva L.C.L.C. 2018 Physiotherapy protocol during initial postoperative period of arthroscopy in horses. Pesquisa Veterinária Brasileira 38(12):2201-2206. Faculdade de Medicina Veterinária e Zootecnia, Universidade de São Paulo, Avenida Prof. Dr. Orlando Marques de Paiva 87, Cidade Universitária, São Paulo, SP 05508-270, Brazil. E-mail: fe.stievani@gmail.com

This study evaluated the effects of a physiotherapy protocol applied in joints with osteochondritis dissecans submitted to arthroscopy. Twelve horses totaling twenty joints were used and divided into two uniform groups, according to articular lesion grade. Treated Group (TG) received the physiotherapy protocol (cryotherapy, passive rage motion and controlled exercise) that initiate just after anesthetic recovery and extended for five days. Control Group (CG) remained resting in stall during the same period. Physical examination and synovial fluid analysis were used to evaluate the treatment. The synovial fluid examination consisted of physical analysis (color, aspect, and viscosity), mucin clot evaluation, Serum Amyloid A, Prostaglandin $E_{2}$ and urea concentration. Synovial samples were collected by arthrocentesis at the beginning of the surgical procedure (D1), 48 hours (D3) and 96 hours (D5) after surgery. Before arthroscopy and daily during the postoperative period joints were evaluated by physical exam: superficial temperature $\left({ }^{\circ} \mathrm{C}\right.$ ), range of motion (degrees) and circumference (centimeters). The joint physical examination showed no significant difference between groups and neither along the days for the same group. The parameters of synovial fluid showed difference over the moments in each group but didn't have difference between groups. Color and aspect had the same patterns across moments, in CG fluid had significant change when compared D1 with D3 (color and aspect: p<0.001) and D5 (color: $\mathrm{p}<0.001$; aspect: $\mathrm{p}<0.05$ ) becoming mostly bloody and cloudy in D3 and D5. However in TG the difference was significant just between D1 and D3 (color and aspect: $\mathrm{p}<0.05$ ), showing an improvement of synovial fluid in D5 (color and aspect: $p>0.05$ ). Viscosity and mucin clot evaluation showed significant change in CG between D1 and D3 (viscosity: $\mathrm{p}<0.01$; mucin clot: $\mathrm{p}<0.05$ ) and between D1 and D5 (viscosity: $\mathrm{p}<0.01$;mucin clot: $\mathrm{p}<0.01$ ). In TG no significant difference of viscosity and mucin clot was observed over the moments, showing an early improvement of synovial fluid quality. The Serum Amyloid A concentration showed an extremely significant increase in CG $(\mathrm{p}<0.001)$ when compared D1 $(1217.13 \pm 664.47 \mu \mathrm{g} / \mathrm{mL})$ and D3 $(42423.80 \pm 52309.31 \mu \mathrm{g} / \mathrm{mL})$. The comparison between D1 and D5 in CG, and across moments in TG, had no statistical difference. The $\mathrm{PGE}_{2}$ eicosanoid remained statistically unchanged all over the time. Urea showed significant increase in D3 when compared to D1 $(\mathrm{p}<0.001)$ in $\mathrm{CG}$, and had no variation in TG. The physiotherapy protocol minimized the inflammatory mediators and provided minor alterations in synovial fluid after arthroscopy.
\end{abstract}

INDEX TERMS: Physiotherapy, arthroscopy, biomarkers, rehabilitation, horses, surgery.

\footnotetext{
${ }^{1}$ Received on February 9, 2018.

Accepted for publication on July 3, 2018.

2 Departamento de Clínicas Veterinárias, Centro de Ciências Agrárias, Universidade Estadual de Londrina (UEL), Rodovia Celso Garcia Km 380, Londrina, Paraná, PR 86057-970, Brazil. *Corresponding author: fe.stievani@gmail.com
}

\footnotetext{
${ }^{3}$ Faculdade de Medicina Veterinária e Zootecnia, Universidade de São Paulo (USP), Avenida Prof. Dr. Orlando Marques de Paiva 87, São Paulo, SP 05508-270, Brazil.

${ }^{4}$ Departamento de Ciências Veterinárias, Universidade Federal do Paraná (UFPR), Rua Pioneiro 2153, Palotina, PR 85950-000, Brazil.
} 
RESUMO.- [Protocolo fisioterápico durante o período pós-operatório inicial de cirurgia artroscópica em equinos.] Este estudo avaliou os efeitos de um protocolo fisioterápico, aplicado em articulações com osteocondrite dissecante, submetidas à artroscopia. Foram utilizados 12 cavalos, totalizando 20 articulações, divididas em dois grupos homogêneos de acordo com a graduação da lesão articular. 0 grupo tratado (GT) recebeu o protocolo fisioterápico (crioterapia, movimentação passiva e exercício controlado) que se iniciou imediatamente após a recuperação anestésica e se estendeu por cinco dias. 0 grupo controle (GC) permaneceu em repouso na baia, pelo mesmo período. Exame físico da articulação e análise do líquido sinovial foram utilizados para avaliar o tratamento. 0 exame do líquido sinovial consistiu em análise física (cor, aspecto e viscosidade), avaliação do coágulo de mucina e concentrações de amiloide sérica A, prostaglandina $\mathrm{E}_{2}$ e ureia. Amostras de líquido sinovial foram colhidas por artrocentese no início do procedimento cirúrgico (D1) e após 48 (D3) e 96 horas (D5) do procedimento cirúrgico. Antes da artroscopia e diariamente no período pós-operatório, as articulações foram avaliadas por exame físico: temperatura superficial $\left({ }^{\circ} \mathrm{C}\right)$, ângulo de flexão (graus), circunferência (centímetros). A avaliação física das articulações não apresentou diferença significativa entre os grupos nem ao longo dos dias em cada grupo. Nas análises do líquido sinovial, observou-se uma variação diferente entre os momentos em cada grupo porém sem diferença significativa entre os grupos. A cor e o aspecto tiveram resultados semelhantes ao longo do tempo, no GC houve uma alteração significativa quando comparados D1 e D3 (cor e aspecto: $\mathrm{p}<0,001$ ) e D1 e D5 (cor: p<0,001; aspecto: $\mathrm{p}<0,05$ ) tornando-se sanguinolento e turvo na maioria das amostras em D3 e D5. Já no GT, houve diferença significativa apenas entre D1 e D3 (cor e aspecto: $p<0,05$ ), demonstrando melhora no líquido sinovial em D5 (cor e aspecto: $p>0,05$ ). A viscosidade e o coágulo de mucina apresentou alteração significativa no GC entre D1 e D3 (viscosidade: $p<0,01$; coágulo de mucina: $\mathrm{p}<0,05$ ) e entre D1 e D5 (viscosidade e coágulo de mucina: $\mathrm{P}<0,01$ ). No grupo tratado não foram observadas alterações significativas em viscosidade e coágulo de mucina, ao longo dos momentos, demonstrando uma melhora precoce na qualidade do líquido sinovial. A amiloide sérica A apresentou um aumento extremamente significante no GC $(\mathrm{p}<0,001)$ quando comparados D1 $(1217,13 \pm 664,47 \mu \mathrm{g} / \mathrm{dL})$ e D3 $(42423,80 \pm 52309,31 \mu \mathrm{g} / \mathrm{dL})$. Quando comparados D1 e D5 no GC e ao longo do tempo no GT não foram observadas diferenças significativas. A concentração de $\mathrm{PGE}_{2}$ permaneceu sem alterações. As mensurações de ureia apresentaram aumento significativo em D3 quando comparado a D1 $(p<0,001)$ no GC e não apresentou variação no GT. 0 protocolo fisioterápico minimizou os mediadores inflamatórios e proporcionou menor alteração do líquido sinovial após artroscopia.

TERMOS DE INDEXAÇÃO: Fisioterapia, artroscopia, articulação, biomarcadores, reabilitação, equinos, cirurgia.

\section{INTRODUCTION}

Degenerative joint disease is a great topic in equine medicine as in humans and it is highly associated with previous acute traumas. People who experience a capsular or ligament trauma presents 10 times more chances of developing osteoarthritis. When the trauma causes an intra-articular fracture, those chances are 20 times more (Anderson et al. 2011). The osteoarthritis physiopathogeny has being studied to permit understand the mechanisms that trigger the acute arthritis and those which perpetuate the disease, resulting in cartilage degeneration and loss of joint function (Olson et al. 2014).

Given the similarity between human and equine joint disease development and considering the athletic use and large volume joints, this specie has being a good model for studies that are intended to elucidate the articular response to injury (Kawcak et al. 2008, Grauw et al. 2009).

The osteochondritis dissecans (OCD) is a developmental orthopedic disease with great importance in sports horses. It has been defined as a focal failure of osteochondral ossification in the articular epiphyseal complex and progress in most of the times for fragmentation inside the joints (Van Weeren 2006, Denoix et al. 2013). Recently has been shown that horses with articular fragment but without pain or joint distention present increased biomarkers for cartilage degradation in the synovial fluid (Machado et al. 2012). When not treated it progress to osteoarthritis and loss of function just like humans post-traumatic arthritis progresses (Van Weeren 2006).

The use of molecular biomarkers in studies focusing on articular dynamics is increasing. Prostaglandin $E_{2}$ has been shown as a great joint disease marker, and has different levels according to the progress of the disease, as chronic, acute or with cartilage lesion already. It has been more sensitive and more specific than TNF- $\alpha$ and IL-1 $\beta$ (Bertone et al. 2001). This eicosanoid was related with the etiology of the osteoarthritis (Kirker-Head et al. 2000). Stålman et al. (2011) affirmed that there are positive correlation between the $\mathrm{PGE}_{2}$ liberation into synovial fluid and the capsular temperature.

Serum Amyloid A (SAA) draws especial attention and is correlated to rheumatoid arthritis during the inflammatory phase when there are angiogenesis and also migration of factors that contribute to perpetuate the inflammation (Mullan et al. 2010). SAA is strongly related to cartilage matrix degradation being one of the factors responsible to induce metalloproteases (MMP) migration inside joint cavity (Connolly et al. 2012). In horses, the acute phase protein, Serum Amyloid A, has also been related to articular disease.

Synovial fluid of healthy horses had unmeasurable values of SAA while injured joints had those values varying according to the disease, and horses that had joint infection reached higher values (Jacobsen et al. 2006). Similarly, serum dosage of SAA varies according to the inflammation generated by the surgical procedure. The more invasive the procedure with large soft tissue trauma higher is SAA values (Jacobsen et al. 2009).

In humans, the physiotherapy is largely used even before articular surgery and extend for weeks during postoperative period. Cryotherapy is associated to pain reduction after arthroscopy (Fang et al. 2012). Passive range of motion was correlated with earlier improvement of joint function after shoulder arthroplasty (Denard \& Lädermann 2016) and controlled exercise has been indicated since the first postoperative day (Wilcox et al. 2005). In equine medicine, physical therapies has been used to prevent sports injury and for rehabilitation. However, there are no studies evidencing the importance of using rehabilitation protocol after joint surgery.

This study objective was to test the efficacy of a physiotherapy protocol applied during the initial postoperative period of 
joints with osteochondritis dissecans submitted to arthroscopic treatment.

\section{MATERIALS AND METHODS}

Ethics statement. The present work was approved by Ethic Committee in the use of animals of the School of Veterinary Medicine and Animal Science of University of São Paulo - USP (2580/2012), and was carried out in accordance with USP guidelines.

Selected joints. Seven metacarpophalangeal, seven metatarsophalangeal and six tibiotarsal joints with diagnosis of osteochondritis dissecans referred to Large Animal Surgery Service of the University of São Paulo and submitted to arthroscopic removal of the fragment and subchondral bone curettage were used for this prospective study.

Study design. During the postoperative period the horses of the control group (CG) rested in stall receiving non-steroidal anti-inflammatory drug (Phenylbutazone $4.4 \mathrm{mg} / \mathrm{kg}$, once a day, for 3 days) and antibiotics (amikacin 15mg/ $\mathrm{kg}$, once a day, for 5 days). On the other side, the horses of the treated group (TG) were submitted additionally to a physiotherapy protocol.

The physiotherapy protocol started right after anesthetic recovery and lasted until the fifth day of postoperative period. It consisted of cryotherapy, passive range of motion and controlled exercise. The cryotherapy was placed over the treated joint using reusable gel packs $\left(\right.$ Mercur $^{\mathrm{TM}}$ ) for the first 72 hours. In the first day, it lasts twenty minutes, every two hours. During the other days, the frequency was every four hours. The passive range of motion started on the second day and it was performed fifteen flexions, twice a day, until the last day. The controlled exercise was hand walking for ten minutes twice a day, which started on the third day.

The studied joints were directed to TG or CG based on intra-articular damage evaluation (Silva 2014) performed during arthroscopy, and based on type of joint, metacarpophalangeal (MCP), metatarsophalangeal (MTP) or tibiotarsal (TT) aiming homogeneous groups. The score was established depending on synovial membrane (color, volume and villus number), articular cartilage surface integrity, and subchondral bone aspect and fragment characteristics (number, size and attachment). As worse the changes on those structures, higher the articular score, ranging from zero to 63 (Silva 2014). The joints had the following distribution in the groups: CG (3MCP, 4MTP and 3TT) and TC (4MCP, 3MTP and 3TT), totaling 10 joints each.

Surgical procedure was always performed during the morning and all animals were equally prepared.

Starting on preoperative period and lasting until fifth day, the joints of both groups were submitted to physical evaluation with the measurement of flexion angle using goniometry, articular circumference in centimeters and superficial temperature with thermography (Flir $440^{\mathrm{TM}}$ ). Physical evaluation was performed every morning before the rehabilitation protocol starts. Synovial samples was collected before arthroscopy (D1), 48hours (D3) and 96 hours after (D5).

Physical evaluation of the synovial fluid. The synovial fluid was evaluated for color, aspect and viscosity using scores from zero to four (Table 1), where zero was the best and four the worst quality for each variant.

Evaluation of mucin clot of the synovial fluid. The volume of $100 \mu \mathrm{L}$ of synovial fluid was added to $2 \mathrm{~mL}$ of $2 \%$ acetic acid. The quality was graded from one to four, where one is a stable and well defined clot that remain on the liquid superficies after slightly
Table 1. Scores for color, aspect and viscosity of the synovial fluid

\begin{tabular}{cccc}
\hline \multirow{2}{*}{ Score } & \multicolumn{3}{c}{ Physical evaluation of synovial fluid } \\
\cline { 2 - 4 } & Color & Aspect & Viscosity \\
\hline 1 & Light yellow & Clear & $>5 \mathrm{~cm}$ \\
2 & Yellow & Slightly cloudy & btw 2 e $5 \mathrm{~cm}$ \\
3 & Xanthochromic & Cloudy & $<2 \mathrm{~cm}$ \\
4 & Bloody & - & -
\end{tabular}

shake and four is a flaccid clot that submerge on fluid even without shaking the tube (Van Pelt 1962).

Prostaglandin $\mathrm{E}_{2}$ and Serum Amyloid A quantification in the synovial fluid. For both analysis the ELISA method was used. The synovial fluid was centrifuged (4000G rotation for 15 minutes at $4^{\circ} \mathrm{C}$ ) and samples was stored at $-80^{\circ} \mathrm{C}$ until analyses. For quantification of Serum Amyloid A de Multi-species Tridelta ${ }^{\mathrm{TM}}$ - EUA Kit was used and for Prostaglandin $\mathrm{E}_{2}$ was used the Cayman Chemical Company ${ }^{\mathrm{TM}}$ EUA Kit.

Synovial fluid concentration of urea. The urea concentration was measured using automatic biochemical analyzer Rendox RX Daytona.

Statistical analysis. Basal comparison for age and articular lesion score were obtained using t-student test and between categorical variables as joint type was used Chi-square test. The evaluation along the time and between the groups was performed with Kruskal-Wallis. To evaluate if the effect along the time was different between groups the Dunn test of multiple comparisons was used. The significance level was $\mathrm{p}<0.05$ for all analyses.

\section{RESULTS}

The articular score obtained for distribution between the two homogeneous groups ranged from 4 (minor damage) to 15 (more damage). The mean of scores were $7.8( \pm 2.35)$ in the CG and $7.0( \pm 3.25)$ in the TG. There was no significant difference between groups $(\mathrm{P}=0.532)$. The horses were less than 10 years old and there was no difference between groups $(\mathrm{p}=0.809)$.

The physical evaluation of the joint, including flexion angle, circumference and superficial temperature didn't shown significant difference between groups neither when compared daily evaluation in the same group.

The synovial fluid parameters showed different presentation over the time. There was difference comparing moments for each group but there was no significant difference between groups.

\section{Synovial fluid physical analysis}

Color. In CG the color worsened from D1 (90\% score 1; $10 \%$ score 2 ) to D3 (20\% score 3; 80\% score 4) with p $<0.001$ and that difference remained when D5 (20\% score 2; 30\% score 3 and 50\% score 4) and D1 were compared. In TG the color worsened only from D1 (80\% score 1; 20\% score 2) to D3 (71\% score 3; $29 \%$ score 4$)$ with $\mathrm{p}<0.05$. However in D5 (62.5\% score $2 ; 25 \%$ score $3 ; 12.5 \%$ score 4 ) the color improved showing no difference when compared with D1 $(p>0.05)$.

Aspect. The fluid aspect evolution was similar to the color. In CG it got more cloudy from D1 (90\% score 1; 10\% score 2) to D3 (30\% score 2 and $70 \%$ score 3 ), with $\mathrm{p}<0,001$, and when 
compared D1 with D5 (10\% score 1; 40\% score 2; 50\% score 3) $\mathrm{p}<0.01$. However in TG the fluid became more cloudy from D1 (70\% score $1 ; 30 \%$ score 2) to D3 (28.6\% score 2; $70 \%$ score 3 ) with $\mathrm{p}<0.01$, and improved to D5 (87.5\% score 2; $12.5 \%$ score 3 ) showing no difference when compared with D1 ( $\mathrm{p}>0.05)$.

Viscosity. The synovial fluid viscosity decreased only in CG when compared D1 (80\% score 1 and 20\% score 2) with D3 (20\% score 2; $70 \%$ score 3 ) and D1 with D5 (10\% score 1; $20 \%$ score 2 and $70 \%$ score 3 ) with $p<0.01$. For the TG there was no difference of synovial fluid viscosity across moments.

\section{Quality of mucin clot of synovial fluid}

The mucin clot variation was similar to viscosity, in CG the mucin clot quality worsened when compared D1 and D3 $(\mathrm{p}<0.05)$ and between D1 and D5 $(\mathrm{p}<0.01)$. In TG however, these changes were not observed (Fig.1) and there was no difference across moments.

\section{Serum Amyloid $\mathbf{A}$ and Prostaglandin $\mathbf{E}_{2}$}

The Serum Amyloid A exhibit an extremely significant rise $(\mathrm{p}<0.001)$ only in CG when compared D1 $(1217.13 \pm 664.47 \mu \mathrm{g} / \mathrm{mL})$ and D3 (42423.80 $\pm 52309.31 \mu \mathrm{g} / \mathrm{mL})$. Between D1 and D5, and across moments in TG it remained unchanged statistically

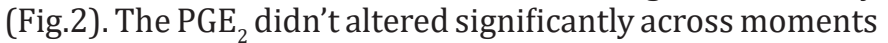
in both groups (Fig.3)

\section{Urea concentration in synovial fluid}

The synovial fluid urea raised was extremely significant in CG at D3 $(33.54 \pm 8.21 \mathrm{mg} / \mathrm{dL})$ in comparison to D1 $(23.35 \pm 3.38 \mathrm{mg} / \mathrm{dL})$ with $\mathrm{p}<0.001$, and in $\mathrm{D} 5$ returned to baseline $29.7 \pm 7.47 \mathrm{mg} / \mathrm{dL}$. In TG it remained unchanged across moments (Fig.4).

\section{DISCUSSION}

The knowledge of articular postoperative injury and the inflammatory response control is important to minimize cartilage degradation and post-traumatic osteoarthritis. The present work evaluated the effects of arthroscopy as well the protective effects of physical therapies to the joint.

We observed that arthroscopy even as a minimally invasive procedure modifies the synovial biomarkers and the synovial fluid quality in all of the operated joints, mainly on the third day, what characterize an acute injury. The establishment of an anti-inflammatory therapy was inherent to the routine of the Veterinary Hospital and even with the use of NSAIDs therapy we found synovial fluid changes in both groups.

Although in other studies the PGE2 has been associated with inflammatory process and MMP increasing into the joint (Grauw et al. 2009), we did not found any significant difference between groups and neither over the time. Our results may be associated to the use of phenylbutazone.

The Serum Amyloid A is an acute phase protein with great importance for the articular space and even in others tissues. It is responsible for induction and maintenance of the inflammation in horses and humans. This protein is believed to be one of the responsible mediators for the leukocyte and monocyte chemotaxis to the inflamed joint and it is able to activate the cytokines (TNF- $\alpha$, IL-6) and MMP production. Those components perpetuate inflammation that results in articular cartilage degradation (Migita et al. 2009,

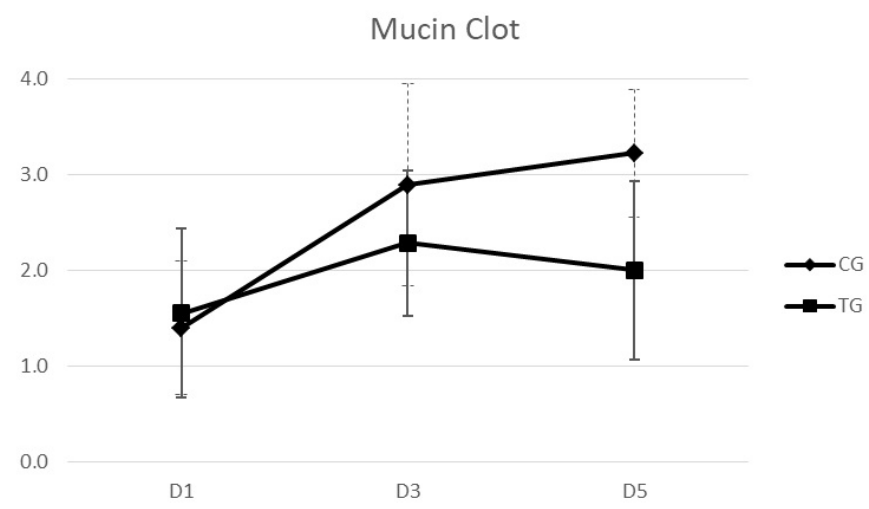

Fig.1. Mucin clot quality evaluation using a scale of 1 to 4 where one is the best quality and four is the poorest quality. D1, D3 and D5 = moments of synovial fluid analysis, before surgery, 48 hours after surgery and 96 hours after surgery respectively. $\mathrm{CG}=$ control group, $\mathrm{TG}=$ treated group .

SAA

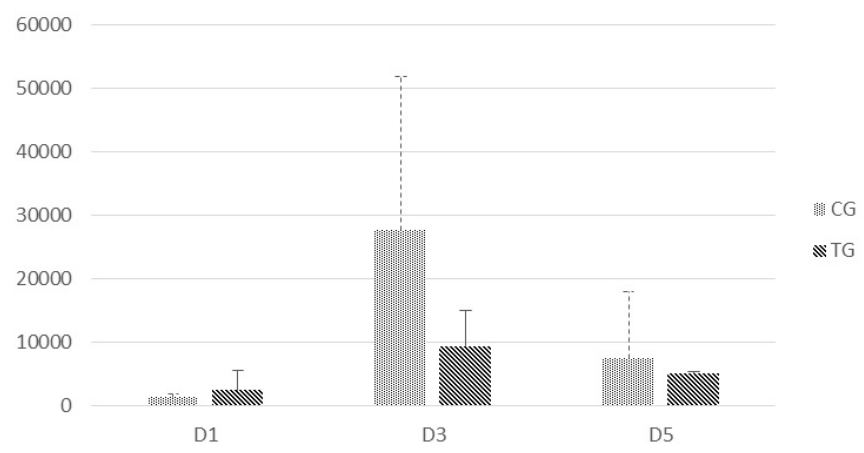

Fig.2. Serum Amyloid A means and standard deviations are represented in $\mu \mathrm{g} / \mathrm{mL}$. D1, D3 and D5 = moments of synovial fluid analysis, before surgery, 48 hours after surgery and 96 hours after surgery respectively. $\mathrm{CG}=$ control group, $\mathrm{TG}=$ treated group.

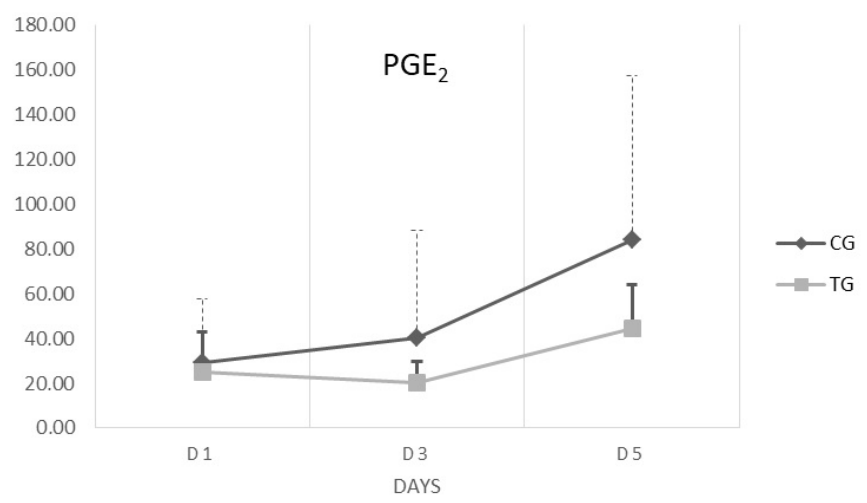

Fig.3. $\mathrm{PGE}_{2}$ concentration means and standard deviation values are represented in pg/mL. D1, D3 and D5 = moments of synovial fluid analysis, before surgery, 48 hours after surgery and 96 hours after surgery respectively. $\mathrm{CG}=$ control group, $\mathrm{TG}=$ treated group.

Connolly et al. 2012). In this work, we observed significant increase in Serum Amyloid A (SAA) concentrations only in D3 of CG. Lower increase of this protein in TG was assigned to 


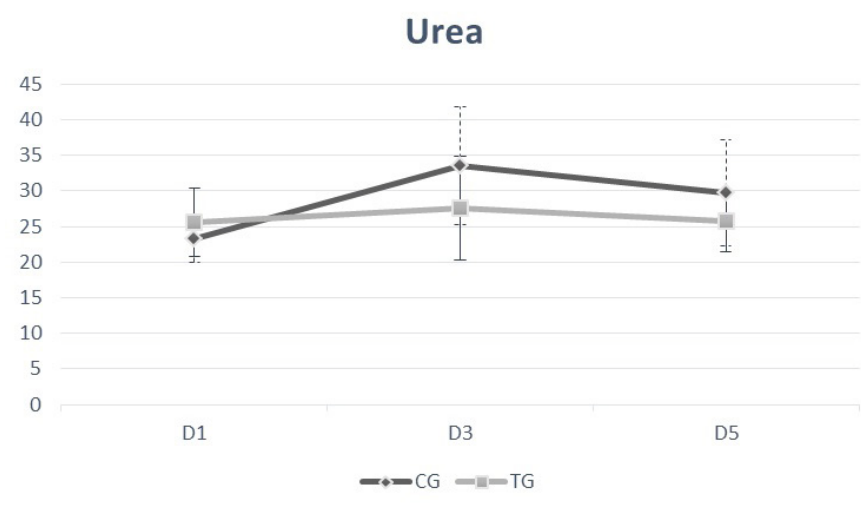

Fig.4. Urea concentration means and standard deviation are shown in $\mu \mathrm{g} / \mathrm{dL}$. D1, D3 and D5 = moments of synovial fluid analysis, before surgery, 48 hours after surgery and 96 hours after surgery respectively. $\mathrm{CG}=$ control group, $\mathrm{TG}=$ treated group.

physiotherapy protocol, especially to the cryotherapy which was intense in the first hours. Previous studies in humans with rheumatoid arthritis, provided that cryotherapy decreased the proinflammatory factors as TNF- $\alpha$ and IL-6, additionally it generated pain relief and functional improvement to treated joints (Jastrazabek et al. 2013).

SAA proved to be a good marker for acute articular inflammation. Despite to be non-significant, even in TG was possible to observe the increase in this protein concentration 48 hours after surgical procedure returning to the baseline at day 5. Our results is in consonance of Lindegaard et al. (2010) that observed the SAA dynamics, after synovitis induction, rising to the top at 48 hours and returning to baseline after 5 days.

The urea measurement is helpful as a correction factor for synovial fluid dilution, when there is an articular effusion and when it is necessary to flush the joint to recover the synovial fluid (Kraus et al. 2002). In this work the urea concentration did not decrease indicating that in both groups the joints did not had effusion. However there was significant increased urea concentration in synovial fluid of CG in D3. We believe that it is related to more intense inflammation inside those joints generating vasodilatation and increased synovial vascular permeability so increasing serum components to the joint. Oliviero et al. (2012) found that inflammatory arthritis feature higher concentration of plasmatic compounds (lipoproteins) because of the increased vascular permeability in those joints.

Considering the physical analysis of the synovial fluid is possible to found important information of joint dynamics, including the nature of disease and lesion extension. The synovial fluid is responsible for the nutrients distribution all over the joint surface and has a mechanical function. A poor synovial fluid quality reflects in the structures nutrition and protection. The bloody color was observed in $80 \%$ of the samples in CG and only 30\% in TG at D3. This result is particularly important because as worse is the hemarthrosis more intense will be the cartilage degradation and greater will be the chance to progress to post-traumatic osteoarthritis (Swärd et al. 2014). The cryotherapy showed a beneficial effect in treated group with less intense bleeding, observed in D3, and faster improvement in synovial quality in D5 compared to CG.
The synovial fluid viscosity is closed related to the quality and quantity of hyaluronic acid in the fluid. Acute inflammations degrade the hyaluronic acid molecule and increase the fluid plasma decreasing its viscosity (Steel 2008). In the present work the synovial fluid viscosity changed only in the CG, with significant decrease over the time. In TG was not observed significant viscosity changes, the fluid was rapidly replaced after surgical procedure and remained with a good quality over the postoperative period.

The mucin clot results were similar to the viscosity. It is believed that the cryotherapy and range of motion promotes better fluid diffusion and better nutrition of all joint structures. The physical analysis and mucin clot of synovial fluid of this study contributes to this affirmation once in TG those parameters had more regular values and recovered faster, with D5 similar to D1.

The range of motion of joints also prevents synovial adhesion formation and limb muscular contracture (Porter 2009). Our results did not show difference of articular flexion angle. These results corroborate to the related by Kim at al. (2012) after human arthroscopy.

The circumference of the joints has been correlated to inflammation, edema formation and increased inflammatory cytokines of the synovial fluid (Szekanecz et al. 2000). Jones et al. (1993) observed enlargement of joints after eight days of carpus arthroscopy. Our results did not show difference in circumference of joints. It may be because all joints remained with bandage until the last measurement in D5 reducing edema formation and joint enlargement.

The superficial temperature did not show difference between groups or across moments. Once the thermography was performed only early in the morning, it is possible that the superficial temperature of the joints returned to normal values after the cryotherapy performed in the evening. Khoshnevis et al. (2015) found that the superficial temperature of knees and ankles submitted to cryotherapy returns to normal values 25 minutes after the end of the technique.

\section{CONCLUSIONS}

The performed physiotherapy protocol on the treated group showed beneficial effects in clinical and laboratory parameters.

The synovial fluid quality of treated group revealed minor inflammatory response, earlier recover of aspect and color and less alteration in viscosity and mucin clot.

Though the obtained results lack of significant difference between groups, the authors encourage the use cryotherapy, passive range of motion and controlled exercise during the initial postoperative period of arthroscopy once we had minimal parameters alteration over the time only in the treated group.

Acknowledgements.- We thank FAPESP for financial support and CAPES for program support.

\section{REFERENCES}

Anderson D.D., Chubinskaya S., Guilak F., Martin J.A., Oegema T.R., Olson S.A. \& Buckwalter J.A. 2011. Post-traumatic osteoarthritis: improved understanding and opportunities for early intervention. J. Orthop. Res. 29(6):802-809. <http://dx.doi.org/10.1002/jor.21359><PMid:21520254> 
Bertone A.L., Palmer J.L. \& Jones J. 2001. Synovial fluid cytokines and eicosanoids as markers of joint disease in horses. Vet. Surg. 30(6):528538. <http://dx.doi.org/10.1053/jvet.2001.28430> <PMid:11704948>

Connolly M., Mullan R.H., McCormick J., Matthews C., Sullivan O., Kennedy A., FitzGerald O., Poole A.R., Bresnihan B., Veale D.J. \& Fearon U. 2012. Acute-phase serum amyloid A regulates tumor necrosis factor $\alpha$ and matrix turnover and predicts disease progression in patients with inflammatory arthritis before and after biologic therapy. Arthritis Rheum. 64(4):10351045. <http://dx.doi.org/10.1002/art.33455> <PMid:22076945>

Denard P.J. \& Lädermann A. 2016. Immediate versus delayed passive range of motion following total shoulder arthroplasty. J. Shoulder Elbow Surg. 25(12):1918-1924. <http://dx.doi.org/10.1016/j.jse.2016.07.032> $<$ PMid:27727055>

Denoix J.M., Jeffcott L.B., McIlwraith C.W. \& Van Weeren P.R. 2013. A review of terminology for equine juvenile osteochondral conditions (JOCC) based on anatomical and functional considerations. Vet. J. 197(1):29-35. <http:// dx.doi.org/10.1016/j.tvjl.2013.03.038> <PMid:23683533>

Fang L., Hung C., Wu S., Fang S. \& Stocker J. 2012. The effects of cryotherapy in relieving postarthroscopy pain. J. Clin. Nurs. 21(5/6):636-643. <http:// dx.doi.org/10.1111/j.1365-2702.2010.03531.x> <PMid:21332855>

Grauw J.C., Van de Lest C.H. \& Van Weeren P.R. 2009. Inflammatory mediators and cartilage biomarkers in synovial fluid after a single inflammatory insult: a longitudinal experimental study. Arthritis Res. Ther. 11(2):2-8. <http://dx.doi.org/10.1186/ar2640> <PMid:19272138>

Jacobsen S., Niewold T.A., Halling-Thomsen M., Nanni S., Olsen E., Lindegaard C. \& Andersen P.H. 2006. Serum amyloid A isoforms in serum and synovial fluid in horses with lipopolysaccharide-induced arthritis. Vet. Immunol. Immunopathol. 110(3/4):325-330. <http://dx.doi.org/10.1016/j. vetimm.2005.10.012><PMid:16337010>

Jacobsen S., Nielsen J.V., Kjelgaard-hansen M., Toelboell T., Fjeldborg J., Hallingthomsen M., Martinussen T. \& Thoefner M.B. 2009. Acute phase response to surgery of varying intensity in horses: a preliminary study. Vet. Surg. 38(6):762-769. <http://dx.doi.org/10.1111/j.1532-950X.2009.00564. x><PMid:19674420>

Jastrazabek R., Straburzyńska-Lupa A., Rutkowski R. \& Romanowski W. 2013. Effects of different local cryotherapies on systemic levels of TNF- $\alpha$, IL-6, and clinical parameters in active rheumatoid arthritis. Rheumatol. Int. 33(8):1053-1060. <PMid:24162563>

Jones D.L., Barber S.M. \& Doige C.E. 1993. Synovial fluid and clinical changes after arthroscopic partial synovectomy of the equine middle carpal joint. Vet. Surg. 22(6):524-530. <http://dx.doi.org/10.1111/j.1532-950X.1993. tb00431.x><PMid:8116210>

Kawcak C.E., Frisbie D.D., Werpy N.M., Park R.D. \& McIlwraith C.W. 2008. Effects of exercise vs experimental osteoarthritis on imaging outcomes. Osteoarthr. Cartilage 16(12):1519-1525. <http://dx.doi.org/10.1016/j. joca.2008.04.015><PMid:18504148>

Khoshnevis S., Craik N.K. \& Diller K.R. 2015. Could-induced vasoconstriction may persist long after cooling ends: an evaluation of multiple cryotherapy units. Knee Surg. Sports Traumatol. Arthrosc. 23(9):2475-2483. <http:// dx.doi.org/10.1007/s00167-014-2911-y> <PMid:24562697>

Kim Y.S., Chung S.W., Kim J.Y., Ok J., Park I. \& Oh J.H. 2012. Is early passive motion exercise necessary after arthroscopic rotator cuff repair? Am. J. Sports Med. 40(4):815-821. <http://dx.doi.org/10.1177/0363546511434287> $<$ PMid:22287641>

Kirker-Head C.A., Chandna V.K., Agarwal R.K., Morris E.A., Tidwell A., O'Callaghan M.W., Rand W. \& Kumar M.S.A. 2000. Concentrations of substance P and prostaglandina E2 in synovial fluid of normal and abnormal joints of horses. Am. J. Vet. Res. 61(6):714-718. <http://dx.doi.org/10.2460/ ajvr.2000.61.714><PMid:10850851>

Kraus V.B., Huebner J.L., Fink C., King J.B., Brown S., Vail T.P. \& Guilak F. 2002. Urea as a passive transport marker for arthritis biomarkers studies. Arthritis Rheum. 46(2):420-427. <http://dx.doi.org/10.1002/art.10124> <PMid:11840444>
Lindegaard C., Gleerup K.B., Thomsen M.H., Martinussen T., Jacobsen S. \& Andersen P.H. 2010. Anti-inflammatory effects of intra-articular administration of morphine in horses with experimentally induced synovitis. Am. J. Vet. Res. 71(1):69-75. <http://dx.doi.org/10.2460/ajvr.71.1.69><PMid:20043783>

Machado T.S.L., Silva L.C.L.C., Baccarin R.Y.A. \& Michelacci Y.M. 2012. Synovial fluid chondroitin sulphate indicates abnormal joint metabolism in asymptomatic osteochondritic horses. Equine Vet. J. 44(4):404-411. <http://dx.doi.org/10.1111/j.2042-3306.2011.00539.x><PMid:22256903>

Migita K., Koga T., Torigoshi T., Maeda Y., Miyashita T., Izumi Y., Aiba Y., Komori A., Nakamura M., Motokawa S. \& Ishibashi H. 2009. Serum amyloid A protein stimulates CCL20 production in rheumatoid synoviocytes. Rheumatology 48(7):741-747. <http://dx.doi.org/10.1093/rheumatology/kep089> <PMid:19447772>

Mullan R.H., McCormick J., Connolly M., Bresnihan B., Veale D.J. \& Fearon U. 2010. A role for the high-density lipoprotein receptor SR-B1 in synovial inflammation via serum amyloid-A. Am. J. Pathol. 176(4):1999-2008. <http://dx.doi.org/10.2353/ajpath.2010.090014> <PMid:20304957>

Oliviero F., Lo Nigro A., Bernardi D., Giunco S., Baldo G., Scanu A., Sfriso P., Ramonda R., Plebani M. \& Punzi L. 2012. A comparative study of serum and synovial fluid lipoprotein levels in patients with various arthritides. Clin. Chim. Acta 413(1/2):303-307. <http://dx.doi.org/10.1016/j. cca.2011.10.019><PMid:22037510>

Olson S.A., Horne P., Furman B., Huebner J., Al-Rashid M., Kraus V.B. \& Guilak F. 2014. The role of cytokines in posttraumatic arthritis. J. Am. Acad. Orthop. Surg. 22(1):29-37. <http://dx.doi.org/10.5435/JAAOS-22-01-29> <PMid:24382877>

Porter M. 2009. Rehabilitation therapy, p.593-597. In: Robinson N.E. \& Sprayberry K.A. (Eds), Current Therapy in Equine Medicine. 6th ed. Saunders Elsevier, St Louis.

Silva M.M. 2014. Desenvolvimento de protocolo de avaliação, por determinação de escore, das alterações encontradas nas doenças articulares em equinos e sua correlação com evolução após tratamento. Tese de Doutorado, Universidade de São Paulo, São Paulo. 94p. Available at <http://www. teses.usp.br/teses/disponiveis/10/10137/tde-13112014-143630/pt-br. php> Accessed on Feb. 9, 2018. <http://dx.doi.org/10.11606/T.10.2014. tde-13112014-143630>.

Stålman A., Berglund L., Dungnerc E., Arner P. \& Felländer-tsai L. 2011. Temperature-sensitive release of prostaglandin E2 and diminished energy requirements in synovial tissue with postoperative cryotherapy: a prospective randomized study after knee arthroscopy. J. Bone Joint Surg. 93(21):1961-1968. <http://dx.doi.org/10.2106/JBJS.J.01790> <PMid:22048090>

Steel C.M. 2008. Equine synovial fluid analysis. Vet. Clin. N. Am., Equine Pract. 24(2):437-454. <http://dx.doi.org/10.1016/j.cveq.2008.05.004> <PMid:18652964>

Swärd P., Struglics A., Englund M., Roos H.P. \& Frobell R.B. 2014. Soft tissue knee injury with concomitant osteochondral fracture is associated with higher degree of acute joint inflammation. Am. J. Sports Med. 42(5):1096-1102. <http://dx.doi.org/10.1177/0363546514524924> <PMid:24664137>

Szekanecz Z., Halloran M.M., Volin M.V., Woods J.M., Strieter R.M., Haines G.K., Kunkel S.L., Burdick M.D. \& Koch A.E. 2000. Temporal expression od inflammatory cytokines and chemokines in rat adjuvant-induced arthritis. Arthritis Rheum. 43(6):1266-1277. <http://dx.doi.org/10.1002/15290131(200006)43:6<1266::AID-ANR9>3.0.CO;2-P><PMid:10857785>

Van Pelt R.W. 1962. Properties of equine synovial fluid. J. Am. Vet. Med. Assoc. 141(9):1051-1061. <PMid:13996105>

Van Weeren P.R. 2006. Osteochondrosis, p.1166-1178. In: Auer J.A. \& Stick J.A. (Eds), Equine Surgery. 3rd ed. Elsevier, St Louis. <http://dx.doi. org/10.1016/B1-41-600123-9/50093-0>.

Wilcox 3rd R.B., Arslanian L.E. \& Millett P. 2005. Rehabilitation following total shoulder arthroplasty. J. Orthop. Sports Physic. Ther. 35(12):821-836. <http://dx.doi.org/10.2519/jospt.2005.35.12.821> <PMid:16848103> 